\title{
The influence of plasma on basal and ACTH-stimulated in vitro adrenocortical steroidogenesis
}

\author{
P J Jenkins ${ }^{1}$, T A Cross ${ }^{1}$, L A Perry ${ }^{2}$, S A Medbak ${ }^{2}$, G M Besser ${ }^{1}$ \\ and A J L Clark ${ }^{\mathbf{C}}$ \\ ${ }^{1}$ Department of Endocrinology, St Bartholomew's and The Royal London Hospital Medical School, Queen Mary and Westfield College, London, UK \\ ${ }^{2}$ Immunoassay Laboratory, Department of Clinical Biochemistry, The Royal Hospitals' NHS Trust, London, UK \\ (Requests for offprints should be addressed to P J Jenkins, Department of Endocrinology, St Bartholomew's Hospital, West Smithfield, London EC1A 7BE, UK)
}

\begin{abstract}
Early descriptions of in vitro ACTH bioassays all emphasised the need to use extracted plasma samples due to interference by an unidentified component. The aim of these studies was to elucidate the effects of whole plasma on ACTH steroidogenic activity in vitro and to identify the responsible factor. A sensitive in vitro dispersed bovine adrenocortical cell bioassay was established. The addition of $10 \%$ ACTH-depleted human pooled plasma to the incubation media resulted in basal steroidogenesis equivalent to that achieved with $10^{-9} \mathrm{M} \mathrm{ACTH} H_{1-24}$ and potentiated the steroidogenic activity of $10^{-9} \mathrm{M}$ ACTH $_{1-24}$ by $7 \cdot 8$-fold. This potentiation was dependent on the concentration of both ACTH and plasma in the media, but did not result from the mitogenic effect of plasma. A pituitary source was excluded and the potentiating activity was not extractable by Vycor glass. Column chromatography demonstrated two peaks of activity corresponding to molecular weights of 650 and $220 \times 10^{3} \mathrm{Da}$. These peaks did not correspond to the plasma binding of
\end{abstract}

${ }^{125}$ I-ACTH which resulted from non-specific binding to albumin. Lipoprotein-deficient serum had no effect on either basal or ACTH-stimulated steroidogenesis, but both were restored by the addition of purified lipoproteins. However, novel findings demonstrated a differential effect of low (LDL) and high (HDL) density lipoproteins on basal and ACTH-stimulated steroid production; thus, LDL exerted a greater effect on the former, whilst HDL potentiated the steroidogenic activity of added ACTH more than LDL. The addition of the lipoproteins to lipoprotein-deficient serum restored its basal and ACTH potentiating effects, the cholesterol concentrations of the chromatographic fractions exactly paralleling their ACTH potentiating effect. These findings suggest that not only are lipoproteins the plasma factor(s) which potentiates ACTH steroidogenic activity in in vitro bioassays, but also that they exert differential effects on basal and ACTH-stimulated steroid production.

Journal of Endocrinology (1999) 162, 155-161

\section{Introduction}

Prior to the introduction of its RIA, measurement of circulating adrenocorticotropin $(\mathrm{ACTH})$ required the use of bioassays, although all of these emphasised the need for extracted plasma samples. In the case of in vivo assays, such as that developed by Lipscomb and Nelson (1962), this was to increase the assay sensitivity, whilst for in vitro bioassays, several workers observed that extraction was necessary to avoid interference in the assay by unidentified substances (Giordano \& Sayers 1971, Lowry et al. 1973, Reader et al. 1982, Lambert et al. 1984). However, despite these observations, only a few preliminary attempts have been made to identify the responsible factor(s). Lowry et al. excluded prostaglandin $\mathrm{E}_{2}$, which had been shown to have an effect in perfused adrenal glands, and insulin, which had been shown to increase the adrenal binding of radiolabelled corticotropin (Lowry et al. 1973, Rees et al.
1973). The modulatory effects of pro-opiomelanocortin (POMC) products other than ACTH, particularly with reference to the $\mathrm{N}$-terminal region, have been investigated by a number of workers, but with conflicting results. Although N-POMC ${ }_{1-76}$ has been shown to have a mild to moderate potentiating effect by some workers (Pedersen \& Brownie 1980, Pedersen et al. 1980, Al-Dujaili et al. 1981), such actions have not been confirmed by other studies (Pham-Huu-Trung et al. 1982, Cathiard et al. 1985).

One possible explanation for any potentiation of in vitro ACTH bioactivity by whole plasma is that it might be due to a specific ACTH binding protein that protects the peptide from proteolytic degradation. This was supported by Upton et al. (1970) who performed crude chromatographic separation of plasma into high $(>4.5 \mathrm{kDa})$ and low $(<4.5 \mathrm{kDa})$ molecular weight fractions after infusion of human and porcine ACTH. They observed that $82 \%$ of 
the bioactive human ACTH was in the high molecular weight fraction, compared with $31 \%$ of the porcine infusion plasma. Fehm et al. (1973) also suggested the presence of an $\mathrm{ACTH}$ binding protein and estimated its size to be $150-200 \times 10^{3} \mathrm{Da}$.

Thus, the existence of a substance in plasma that is capable of modulating the in vitro steroidogenic activity of ACTH has been documented by endocrinologists for over 20 years, but to date its identity has remained unknown. The aims of our investigation were: (1) to clarify the in vitro effect of human plasma on basal and ACTHstimulated glucocorticoid synthesis by adrenal zona fasiculata and reticularis cells, (2) to characterise and identify any modulatory plasma factors, and (3) to clarify the existence of a specific plasma ACTH binding protein.

\section{Materials and Methods}

\section{Dispersed adrenal cell bioassay}

An in vitro dispersed adrenocortical ACTH bioassay was established based on previously described methodology (Tait et al. 1980, Bird et al. 1991). Fresh bovine adrenal glands were obtained from an abattoir within $20 \mathrm{~min}$ of slaughter. Each gland was slowly perfused, via the adrenal artery, with $30 \mathrm{ml}$ warm Earles' balanced salt solution (EBSS) to remove red corpuscles, cut in a sagittal direction and the yellow medullary tissue removed. The underlying zona reticularis and fasiculata were gently scraped off leaving a 1-mm rim comprising the zona glomerulosa and capsule. The tissue from each gland was incubated for $90 \mathrm{~min}$ at $37^{\circ} \mathrm{C}$ in $30 \mathrm{ml}$ EBSS containing $2 \mathrm{mg} / \mathrm{ml}$ collagenase (Worthington Class 1; lot no. S4S088, Worthington Biochemical Corporation, Halls Mill Road, Freehold, NJ, USA). Any remaining clumps of tissue were further dispersed by vigorously bubbling air through the $50 \mathrm{ml}$ tube using a Pipette-Aid; the resultant suspension was filtered over $250 \mu \mathrm{m}$ nylon gauze and washed three times with warm EBSS. The number and viability of the dispersed cells was assessed using Trypan blue and a haemocytometer and cells were plated into $12-$ well plates at a concentration of $5 \times 10^{5}$ cells/well. One millilitre Ham's F12 medium, containing 10\% fetal calf serum, penicillin $100 \mathrm{IU} / \mathrm{ml}$, streptomycin $100 \mu \mathrm{g} / \mathrm{ml}$ and $\beta$-amphotericin $0 \cdot 25 \mu \mathrm{g} / \mathrm{ml}$ was added to each well, and incubated for $24 \mathrm{~h}$ at $37^{\circ} \mathrm{C}$ in $5 \% \mathrm{CO}_{2}$. Cells were then washed twice with warm EBSS containing $0 \cdot 2 \%$ bovine serum albumin (BSA), after which they were ready for stimulation with the substances under investigation. In each experiment, the final volume in each well was made up to $500 \mu \mathrm{l}$ with EBSS $+0 \cdot 2 \%$ BSA. Stimulated cells were incubated for a further $24 \mathrm{~h}$, after which the incubation medium was carefully removed and stored at $-20{ }^{\circ} \mathrm{C}$ prior to measuring the cortisol concentration by RIA. Using this protocol, the minimum detectable concentration of $\mathrm{ACTH}_{1-24}$ was $5 \times 10^{-12} \mathrm{M}(34 \mathrm{pg} / \mathrm{ml})$ with a maximum response occurring between $10^{-9}$ and $5 \times$ $10^{-9}$ M. Similar results were obtained with $\mathrm{ACTH}_{1-39}$.

The intra- and interassay precisions for the steroidogenic effect of $10^{-9} \mathrm{M} \mathrm{ACTH}_{1-24}$ were $8 \cdot 3 \%$ and $67 \%$ respectively. Each study was performed in triplicate and each experiment repeated on three occasions. In order to overcome the interassay variability and to allow comparisons to be drawn between different experiments all values are expressed as a ratio of the steroidogenic effect of $10^{-9} \mathrm{M} \mathrm{ACTH}_{1-24}$ which was used in each experiment.

\section{Effect of human plasma on ACTH steroidogenic activity}

Pooled plasma was used in which all the endogenous ACTH had been proteolytically cleaved by leaving at room temperature for $24 \mathrm{~h}$, as evidenced by undetectable levels in an ACTH RIA. Ten percent by volume of plasma was added to the incubation media in each well, with and without $\mathrm{ACTH}_{1-24}$ (final concentration $\left.10^{-9} \mathrm{M}\right)$. The effect of temperature was assessed by using plasma that had been heated to $37^{\circ} \mathrm{C}$ or $55^{\circ} \mathrm{C}$ for $12 \mathrm{~h}$. Modulation by a POMC or pituitary factor was investigated by studying plasma samples from patients with (1) isolated ACTH deficiency, (2) panhypopituitarism following transsphenoidal surgery and (3) following the administration of dexamethasone to normal subjects (0.5 mg 6-hourly for $48 \mathrm{~h}$ ); the mean ACTH levels before and after dexamethasone were $23 \mathrm{pg} / \mathrm{ml}$ and $<10 \mathrm{pg} / \mathrm{ml}$ respectively.

The mitogenic effect of plasma was assessed by measuring the total DNA content of the wells, according to the method of West et al. (1985).

\section{Influence of Vycor glass extraction on ACTH potentiation}

Three test samples (final volume $2 \mathrm{ml}$ ) were made up containing either 10\% ACTH-deficient plasma, $10^{-8} \mathrm{M}$ ACTH, or both combined. To each tube was added $1 \mathrm{ml}$ silica glass 'Vycor' (previously activated by heating to $600{ }^{\circ} \mathrm{C}$ for $1 \mathrm{~h}$ ) suspension $(50 \mathrm{mg} / \mathrm{ml}$ water) and after gentle mixing for $30 \mathrm{~min}$ at room temperature, the supernatant was removed and stored at $-20^{\circ} \mathrm{C}$. The remaining Vycor pellet was subjected to acid-acetone extraction with the extract being reconstituted in EBSS. Seventy-five microlitres of both the extracts and original supernatants were added to the assay wells with and without the addition of $\mathrm{ACTH}_{1-24}$ (final concentration $10^{-9} \mathrm{M}$ ).

\section{Estimation of the molecular weight of the modulatory factor}

Chromatographic separation of plasma was performed using washed, degassed Sephacryl S300 (separation range of globular proteins of $\left.10-1500 \times 10^{3} \mathrm{Da}\right)$ in a $90 \times$ $0.9 \mathrm{~cm}$ glass column. The eluant was EBSS $+0 \cdot 2 \%$ BSA at $\mathrm{pH} 7 \cdot 4$ passed at a rate of $6 \mathrm{ml} / \mathrm{h}$ with $1 \mathrm{ml}$ fractions collected. The void volume $\left(\mathrm{V}_{0}\right)$ and total volume $\left(\mathrm{V}_{\mathrm{t}}\right)$ 
were determined using dextran blue and ${ }^{125} \mathrm{I}$-ACTH respectively and the column calibrated with known molecular weight markers $\left(45-650 \times 10^{3} \mathrm{Da}\right)$. After priming with plasma and equilibration for $48 \mathrm{~h}, 1 \mathrm{ml}$ spun plasma was loaded onto the column. From each fraction $450 \mu \mathrm{l}$ were added directly to the assay wells together with $50 \mu \mathrm{l}$ $10^{-8} \mathrm{M} \mathrm{ACTH}$; each fraction was assayed in duplicate.

\section{Evaluation of an ACTH binding protein}

Comparison was made of the radiochromatographic profiles after ${ }^{125}$ I-ACTH had been incubated in plasma or EBSS and passed over the Sephacryl column. Both mixtures were incubated for $2 \mathrm{~h}$ at room temperature and eluted at a rate of $6 \mathrm{ml} / \mathrm{h}$ with $1 \mathrm{ml}$ fractions collected. Subsequent experiments determined the effect of temperature (incubation at $4{ }^{\circ} \mathrm{C}$ for $60 \mathrm{~min}$ ) or mercaptoethanol upon the binding. The binding specificity was assessed by comparison with incubation in a physiological albumin solution $(40 \mathrm{~g} / \mathrm{l})$ and the displacement by a 100-fold excess of 'cold' ACTH.

\section{Specificity of plasma in potentiating ACTH-stimulated glucocorticoid synthesis}

The specificity of the plasma potentiation to glucocorticoid secretion was assessed by the measurement of other adrenocortical hormones, androstenedione and testosterone, in the bioassay after stimulation by $10^{-9} \mathrm{M}$ $\mathrm{ACTH}_{1-24}$ and $10 \%$ plasma. Specificity to ACTH was assessed by observing the effects of plasma on glucocorticoid production in response to $10^{-8}$ and $10^{-9} \mathrm{M}$ angiotensin II (AII).

\section{Cholesterol as a modifier of ACTH steroidogenic activity}

The influence of exogenous cholesterol upon the steroid production by the bioassay was assessed. Studies were performed using (1) lipoprotein-deficient serum (LPDS) and (2) purified high density (HDL) and low density (LDL) lipoproteins, prepared by density ultracentrifugation and membrane dialysation from the same plasma pool (Schumaker \& Puppione 1986). The cholesterol concentrations of the purified LDL and HDL were $15 \cdot 7$ and $9.9 \mathrm{mmol} / 1$ respectively. To each bioassay well was added $50 \mu \mathrm{l}$ LPDS or LDL or HDL without and with the simultaneous addition of $50 \mu 10^{-8} \mathrm{M} \mathrm{ACTH}_{1-24}$. Finally, comparison was made of the potentiating effect and the cholesterol content of the chromatographic fractions of plasma. Total cholesterol content was measured by an enzymatic assay (Nanjee et al. 1996).

\section{Results}

\section{Effect of human plasma on ACTH steroidogenic activity}

Although on its own $10 \%$ plasma resulted in steroidogenesis equivalent to $10^{-9} \mathrm{M} \mathrm{ACTH}_{1-24}$ there was a marked

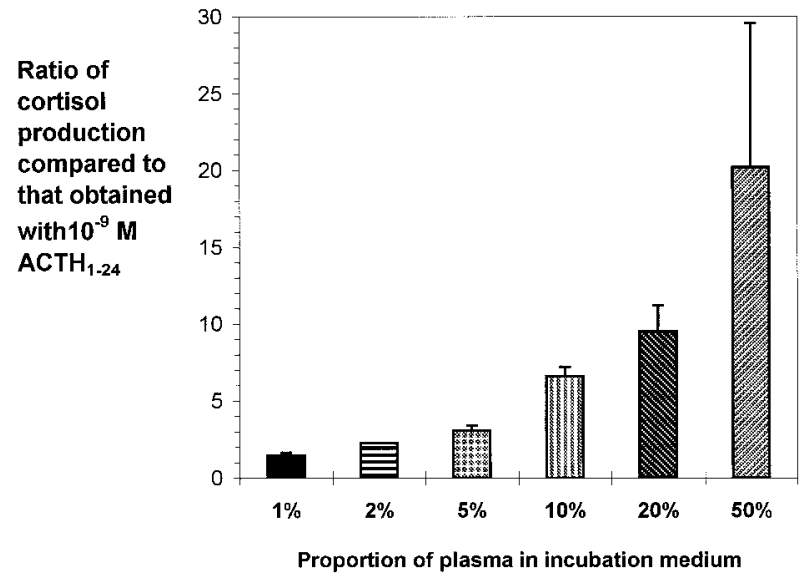

Figure 1 The effect of different proportions of plasma in the incubation medium on $10^{-9} \mathrm{M} \mathrm{ACTH}_{1-24^{-}}$-timulated steroidogenesis. Values are the means \pm S.E.M. of 3 experiments with each performed in triplicate.

synergistic effect when it was combined with $10^{-9} \mathrm{M}$ $\mathrm{ACTH}_{1-24}$, resulting in a $7 \cdot 8$-fold increase in cortisol production. There was no loss of basal or potentiating activity using plasma heated to either $37^{\circ} \mathrm{C}$ or $55^{\circ} \mathrm{C}$. The potentiating effect was dependent on both the ACTH concentration and that of plasma, occurring with as little as $1 \%$ by volume. The addition of $20 \%$ and $50 \%$ plasma caused respectively a $1 \cdot 6$ - and $3 \cdot 2$-fold increase in basal cortisol production compared with that from $10^{-9} \mathrm{M}$ $\mathrm{ACTH}_{1-24}$, and a 9.6- and 20-fold increase in $10^{-9} \mathrm{M}$ $\mathrm{ACTH}_{1-24}$-stimulated steroid secretion (Fig. 1). The time course of the ACTH potentiation mirrored that of ACTH alone, both beginning within $30 \mathrm{~min}$ and reaching a maximum effect after $8 \mathrm{~h}$ incubation. A POMC or pituitary source of the potentiating factor was excluded because both the basal and ACTH potentiating activity of plasma from the three patient groups was the same as normal plasma.

That the potentiation was not a reflection of increased cell numbers was excluded by the DNA content of the wells. Although compared with $10^{-9} \mathrm{M}$ ACTH $10 \%$ plasma on its own resulted in an increased DNA concentration, there was no further increase with the combination of plasma and ACTH.

\section{Influence of Vycor glass extraction on ACTH potentiation}

Figure 2 shows the potentiating effects of the extract and supernatant of plasma, ACTH or both combined on ACTH steroidogenic activity. As expected, the extract of the ACTH sample resulted in significant steroidogenesis, whilst the ACTH supernatant had minimal activity. In contrast, stimulation with the plasma extract resulted in little enhancement of steroidogenesis, whilst the supernatant resulted in a $3 \cdot 1$-fold potentiation. 


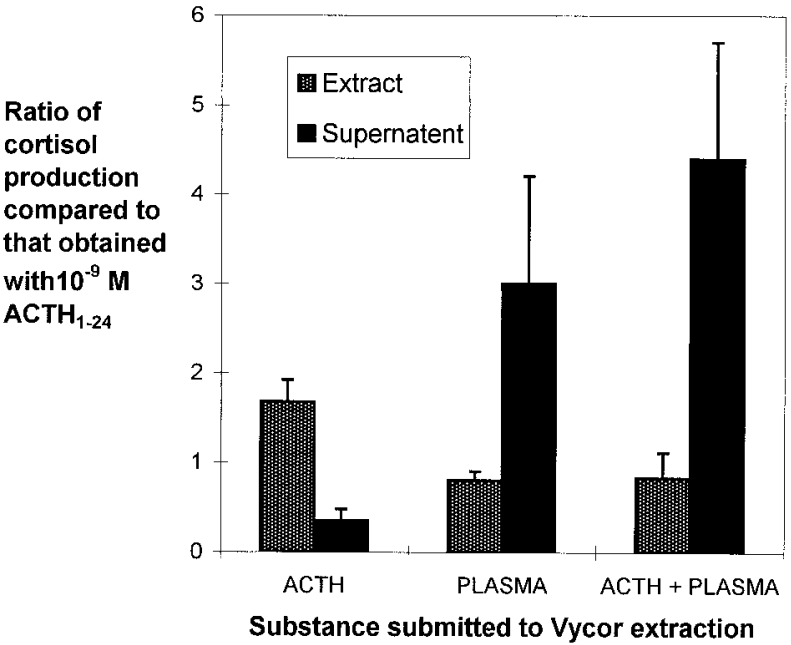

Figure 2 The steroidogenic activity of the Vycor extract and supernatant of $10^{-9} \mathrm{M} \mathrm{ACTH}_{1-24} \pm$ plasma after addition to $10^{-9} \mathrm{M} \mathrm{ACTH}_{1-24}$. Values are the means \pm S.E.M. of 3 experiments with each performed in triplicate.

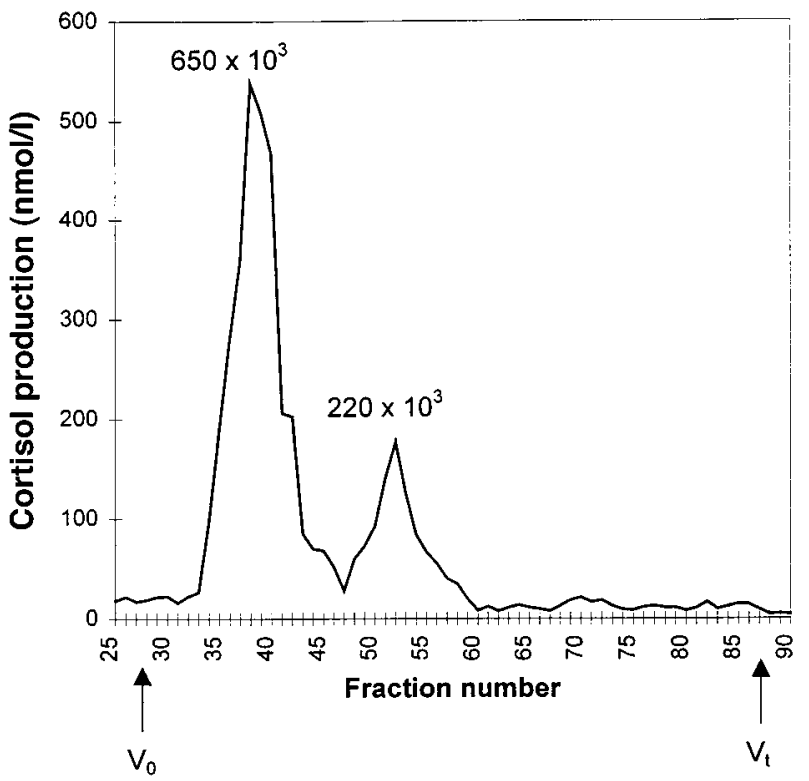

Figure 3 A representative graph of the enhancement of $10^{-9} \mathrm{M}$ $\mathrm{ACTH}_{1-24}$-stimulated steroidogenesis by chromatographic fractions obtained from plasma passed over a Sephacryl S300 column. Each value was performed in duplicate.

\section{Estimation of the molecular weight of the potentiating factor}

Figure 3 is a representative graph of the potentiating effect of fractions 25-92 on $\mathrm{ACTH}_{1-24}$-stimulated steroidogenesis. Repeated experiments confirmed the findings. Two peaks of potentiation were obtained that corresponded to molecular weights of $650 \times 10^{3}$ and $220 \times 10^{3} \mathrm{Da}$ respectively, but with the former being the more active.

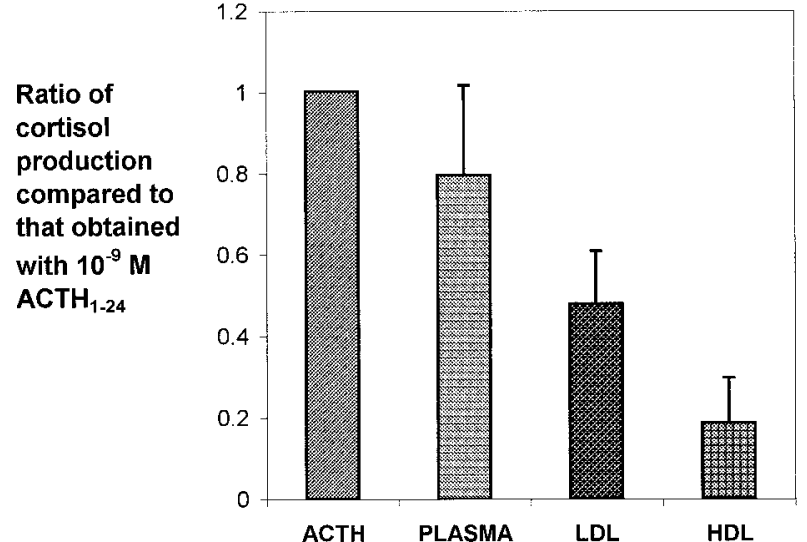

Figure 4 The steroidogenic activity of LDL or HDL on basal steroidogenesis. Values are the means \pm S.E.M. of 3 experiments with each performed in triplicate.

\section{Evaluation of an ACTH binding protein}

Column chromatography with radiolabelled ACTH showed that ${ }^{125} \mathrm{I}_{-} \mathrm{ACTH}_{1-39}$ incubated with EBSS appeared after $V_{t}$, whilst after incubation with plasma there was a sharp peak that appeared at fraction 74 , corresponding to an approximate molecular weight of $40 \times 10^{3} \mathrm{Da}$. This binding was unaffected by temperature or mercaptoethanol. An identical peak of binding was obtained following incubation in albumin and there was no displacement by the addition of excess 'cold' $\mathrm{ACTH}_{1-39}$.

Specificity of plasma in potentiating ACTH-stimulated steroid synthesis

$10^{-9} \mathrm{M}$ ACTH stimulated the secretion of both androstenedione and testosterone into the medium, and secretion was potentiated $5 \cdot 2$ - and 3.4-fold respectively by the addition of $10 \%$ plasma. Plasma also enhanced the production of cortisol in response to $10^{-8}$ and $10^{-9} \mathrm{M}$ angiotensin-II by up to 18 -fold.

\section{The effects of cholesterol on ACTH steroidogenic activity}

LPDS by itself caused no detectable steroidogenesis and no potentiation of ACTH. 10\% LDL (final cholesterol concentration $1.57 \mathrm{mmol} / \mathrm{l}$ ) resulted in basal steroidogenesis $0 \cdot 6$ - and $0 \cdot 47$-fold respectively that obtained with $10 \%$ plasma and $10^{-9} \mathrm{M}$ ACTH, whilst 10\% HDL (final cholesterol concentration $1.0 \mathrm{mmol} / \mathrm{l}$ ) was less potent, being $0 \cdot 23$ - and $0 \cdot 18$-fold as effective respectively (Fig. 4). However, an opposite pattern of results was observed in their potentiation of $10^{-9} \mathrm{M} \mathrm{ACTH}_{1-24}$ steroidogenic activity with $10 \%$ LDL causing a 4 -fold increase $(0 \cdot 4$ times as potent as whole plasma), whereas $10 \% \mathrm{HDL}$ potentiated 


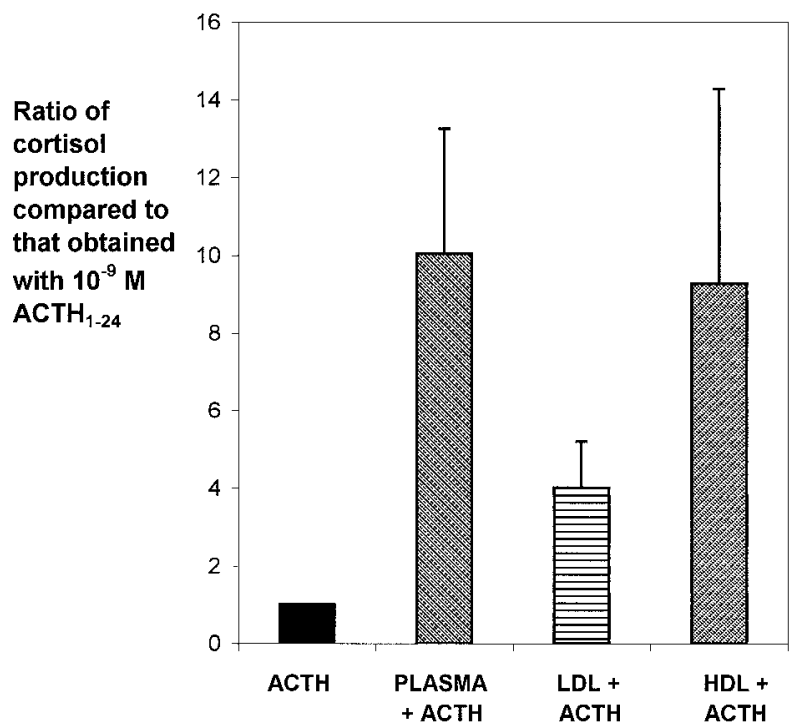

Figure 5 The enhancement by $\mathrm{LDL}$ and $\mathrm{HDL}$ of $10^{-9} \mathrm{M}$ ACTH ${ }_{1-24}$-stimulated steroidogenic activity. Values are the means \pm S.E.M. of 3 experiments with each performed in triplicate.

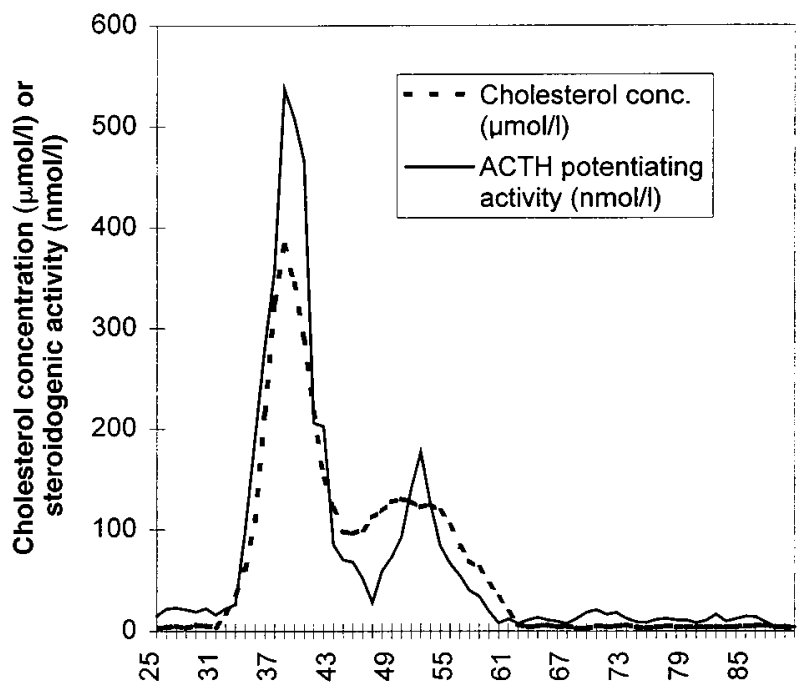

Fraction number

Figure 6 The cholesterol content and $10^{-9} \mathrm{M} \mathrm{ACTH}_{1-24}$ enhancing activity of fractions obtained from chromatographic separation of plasma. Each value was performed in duplicate.

the effects of ACTH 9.2-fold (0.9 times as effective as whole plasma) (Fig. 5). In combination, their effects were additive with a $12 \cdot 8$-fold increase in steroid production. The cholesterol content of the chromatographic fractions paralleled their ACTH potentiating activity (Fig. 6).

\section{Discussion}

Although previous workers have suggested the existence of an ACTH binding protein (Fehm et al. 1972, Nicholson et al. 1984), our results suggest that such binding is due to non-specific interaction to albumin. Not only did the highest binding correspond to a molecular weight of approximately $40 \times 10^{3} \mathrm{Da}$, indistinguishable from that of albumin, but a similar peak was observed when ${ }^{125} \mathrm{I}-$ ACTH was incubated with a physiological concentration of albumin. Furthermore, plasma-bound ${ }^{125} \mathrm{I}-\mathrm{ACTH}$ could not be displaced by the addition of excess 'cold' ACTH. These observations support those of Muramoto and Ramachandran (1981) who also documented binding of ACTH to albumin.

We have provided strong evidence that the factor(s) in human plasma that potentiates its in vitro steroidogenic activity is cholesterol in the form of lipoproteins. These findings explain the majority of earlier reports using in vitro dispersed adrenal cell bioassays, in which human plasma was observed to alter the shape of the steroidogenic dose-response curve (Giordano \& Sayers 1971, Lowry et al. 1973, Lambert et al. 1984). The influence of lipoproteins on steroidogenesis has also been investigated by previous workers, although the majority of studies have been performed from a non-endocrinological perspective with the primary interest being directed towards the biochemistry of cholesterol per se and its subsequent uptake and metabolism, rather than the modulation of glucocorticoid secretion and synthesis. These studies on lipoprotein metabolism have revealed that LDL-cholesterol is preferentially utilised in mice (Faust et al. 1977) and human fetal cells (Simpson et al. 1979, Carr et al. 1980, Higashijima et al. 1987), whilst HDL-cholesterol is the preferred substrate in rats (Gwynne et al. 1976, Andersen \& Dietschy 1978, Gwynne \& Hess 1980). Studies using bovine adrenocortical cells have demonstrated variable results and few have directly compared the relative effects of HDL and LDL, although preincubation with either lipoprotein increased both basal and ACTH-stimulated steroidogenesis (Koper et al. 1985). No difference between the two was observed in ACTH-stimulated steroid production, even at high ACTH concentrations $\left(10^{-7} \mathrm{M}\right)$ (Higashijima et al. 1987), whilst another revealed HDL to have a greater effect on both basal and ACTH $\left(10^{-7} \mathrm{M}\right)$-stimulated steroidogenesis (Yaguchi et al. 1998). Kovanen et al. (1979) observed that LDL but not HDL increased basal production, but did not investigate their influence on ACTH. A 5-fold increase in ACTH-stimulated $(50 \mathrm{nM})$ cortisol production was recorded with human LDL after prolonged stimulation but comparison with human HDL was not made (Rainey et al. 1992). In addition, HDL, but not LDL, has also been reported to increase basal and AII-stimulated mineralocorticoid production by bovine zona glomerulosa cells (Knorr et al. 1988). 
Our results from direct comparisons between LDL and HDL on basal and ACTH-stimulated steroid production are broadly in agreement with these studies (Koper et al. 1985, Knorr et al. 1988). We observed that both LDL and HDL increased basal secretion but with LDL being more potent, whilst opposite effects were observed on ACTHstimulated steroidogenesis with HDL having a greater effect. The mechanisms that might explain these novel differential effects are uncertain. Under basal conditions, LDL might be preferentially taken up by adrenocortical cells, via endocytic internalisation of its specific receptor (Brown et al. 1979). The existence of such a receptor for HDL remains controversial and although attachment to the plasma membrane does occur, free cholesterol is preferentially taken up (up to 8-fold greater) rather than the intact molecule and its associated lipoprotein (Simpson 1979, Azhar et al. 1989, Reaven et al. 1989). Such uptake might be increased in the presence of ACTH.

An alternative explanation is that HDL is able to influence ACTH signal transduction. Alterations in membrane cholesterol:phospholipid ratio that influence its fluidity have been shown to affect membrane bound adenylate cyclase activity (Sinha et al. 1977, Sinensky et al. 1979, Whetton et al. 1983) and cause conformational transitions within the ACTH molecule that alter its interaction with the receptor (Nabedryk-Viala et al. 1978, Gysin \& Schwyzer 1984). Functional studies have suggested that such alterations might have a physiological significance. Experimentally increasing the plasma membrane cholesterol:phospholipid ratio of adrenal cells, without adverse effects on cell viability, significantly increases production of ACTH-stimulated steroids and cAMP (Iida et al. 1987). Whether such membrane effects explain our results remains unproven. It is known that there is a bidirectional flux of cholesterol between cells and lipoproteins and the binding of HDL to the cell membrane can promote the translocation of cholesterol to the plasma membrane from intracellular stores (Johnson et al. 1986, Slotte et al. 1987). A combination of this and the preferential uptake of free cholesterol from HDL (Azhar et al. 1989, Reaven et al. 1989) might result in the cholesterol enrichment of adrenocortical plasma membranes leading to changes in membrane fluidity and thus ACTH binding and receptor conformation. Some circumstantial evidence in support of this is the observation that whilst HDL is able to potentiate ACTH-stimulated steroidogenesis, it does not suppress intracellular ACTH-promoted induction of HMG CoA reductase, unlike LDL (Rainey et al. 1992).

In conclusion, these observations suggest that lipoproteins are the principal constituents responsible for the interference by plasma of in vitro adrenocortical bioassays. In the absence of ACTH LDL is preferentially utilised for steroidogenesis, whilst in its presence HDL exerts a greater potentiating effect. The precise mechanisms for these differential effects remain to be determined.

\section{References}

Al-Dujaili EAS, Hope J, Estivariz FE, Lowry PJ \& Edwards CRW 1981 Circulating human pituitary pro-y-melanotropin enhances the adrenal response to ACTH. Nature 291 156-159.

Andersen JM \& Dietschy JM 1978 Relative importance of high and low density lipoproteins in the regulation of cholesterol synthesis in the adrenal gland, ovary, and testis of the rat. Journal of Biological Chemistry 253 9024-9032.

Azhar S, Stewart D \& Reaven E 1989 Utilization of cholesterol-rich lipoproteins by perfused rat adrenals. Journal of Lipid Research $\mathbf{3 0}$ 1799-1810.

Bird IM, Clyne CD, Lightly ERT, Williams BC \& Walker SW 1991 Further characterisation of the steroidogenic responsiveness of purified zona fasciculata/reticularis cells from bovine adrenal cortex before and after primary culture: changing responsiveness to phosphoinositidase C agonists. Journal of Endocrinology 133 21-28.

Brown MS, Kovanen PT \& Goldstein JL 1979 Receptor-mediated uptake of lipoprotein-cholesterol and its utilization for steroid synthesis in the adrenal cortex. Recent Progress in Hormone Research 35 215-257.

Carr BR, Porter JC, MacDonald PC \& Simpson ER 1980 Metabolism of low density lipoprotein by human fetal adrenal tissue. Endocrinology 107 1034-1040.

Cathiard AM, Durand PH, Seidah MG, Chretien M \& Saez JM 1985 Effects of several pro-opiomelanocortin-derived peptides on steroidogenesis in ovine and bovine adrenal cells. Journal of Steroid Biochemistry and Molecular Biology 23 185-190.

Faust JR, Goldstein JL \& Brown MS 1977 Receptor-mediated uptake of low density lipoprotein and utilization of its cholesterol for steroid synthesis in cultured mouse adrenal cells. Journal of Biological Chemistry 252 4861-4871.

Fehm HL, Voigt KH \& Pfeiffer EF 1972 Problems and artefacts in ACTH assay. Hormone and Metabolic Research 4 477-481.

Fehm HL, Voigt KH, Lang R, Ozyol MB \& Pfeiffer EF 1973 Influence of plasma on ACTH-stimulated corticosterone production of isolated adrenal cells. FEBS Letters 36 109-112.

Giordano ND \& Sayers G 1971 Isolated adrenal cells: assay of ACTH in rat serum. Proceedings of the Society for Experimental Biology and Medicine 136 623-626.

Gwynne JT \& Hess B 1980 The role of high density lipoproteins in rat adrenal cholesterol metabolism and steroidogenesis. Journal of Biological Chemistry 255 10875-10883.

Gwynne JT, Mahaffee D, Brewer HB Jr \& Ney RL 1976 Adrenal cholesterol uptake from plasma lipoproteins: regulation by corticotropin. Proceedings for the National Academy of Sciences of the USA 73 4329-4333.

Gysin B \& Schwyzer R 1984 Hydrophobic and electrostatic interactions between adrenocorticotropin-(1-24)-tetracosapeptide and lipid vesicles. Amphiphilic primary structures. Biochemistry 23 1811-1818.

Higashijima M, Nawata H, Kato K \& Ibayashi H 1987 Studies on lipoprotein and adrenal steroidogenesis. I. Roles of low density lipoprotein- and high density lipoprotein-cholesterol in steroid production in cultured human adrenocortical cells. Endocrinologia Japonica 34 635-645.

Iida S, Widmaier EP \& Hall PF 1987 The influence of plasma membrane cholesterol on the response of adrenal cells to adrenocorticotropin. Endocrinology 120 801-808.

Johnson WJ, Bamberger MJ, Latta RA, Rapp PE, Phillips MC \& Rothblat GH 1986 The bidirectional flux of cholesterol between cells and lipoproteins. Effects of phospholipid depletion of high density lipoprotein. Journal of Biological Chemistry 261 5766-5776.

Knorr M, Locher R, Vogt E, Vetter W, Block LH, Ferracin F, Lefkovits H \& Pletscher A 1988 Rapid activation of human platelets by low concentrations of low-density lipoprotein via phosphatidylinositol cycle. European Journal of Biochemistry 172 753-759. 
Koper WJ, Cordle SR \& Yeaman SJ 1985 Effect of high and low density lipoproteins on corticotropin-mediated cortisol synthesis by bovine zona fasciculata cells. Journal of Steroid Biochemistry and Molecular Biology 23 369-371.

Kovanen PT, Faust JR, Brown MS \& Goldstein JL 1979 Low density lipoprotein receptors in bovine adrenal cortex. I. Receptormediated uptake of low density lipoprotein and utilization of its cholesterol for steroid synthesis in cultured adrenocortical cells. Endocrinology 104 599-609.

Lambert A, Frost J \& Robertson WR 1984 Preliminary experiences with a bioassay for adrenocorticotrophin (ACTH) in unextracted human plasma using dispersed guinea-pig adrenal cells. Clinical Endocrinology 21 33-41.

Lipscomb HS \& Nelson DM 1962 A sensitive biological assay for ACTH. Endocrinology 71 13-23.

Lowry PJ, McMartin C \& Peters J 1973 Properties of a simplfied bioassay for adrenocorticotrophic activity using the steroidogenic response of isolated adrenal cells. Journal of Endocrinology 59 43-55.

Muramoto K \& Ramachandran J 1981 Identification of the corticotropin binding domain of bovine serum albumin by photoaffinity labeling. Biochemistry 20 3380-3385.

Nabedryk-Viala E, Thiery C, Calvet P, Fermandjian S, Kisfaludy L \& Thiery JM 1978 Conformation of corticotropin. An infrared spectrometry study of hydrogen exchange kinetics. Biochimica et Biophysica Acta 536 252-262.

Nanjee MN, Crouse JR, King JM, Hovorka R, Rees SE, Carson ER, Morgenthaler J, Lerch P \& Miller NE 1996 Effects of intravenous infusion of lipid-free apo A-I in humans. Arteriosclerosis and Thrombosis and Vascular Biology 16 1203-1214.

Nicholson WE, Davis DR, Sherrell BJ \& Orth DN 1984 Rapid radioimmunoassay for corticotropin in unextracted human plasma. Clinical Chemistry 30 259-265.

Pedersen RC \& Brownie AC 1980 Adrenocortical response to corticotropin is potentiated by part of the amino-terminal region of pro-corticotropin/endorphin. Proceedings of the National Academy of Sciences of the USA 77 2239-2243.

Pedersen RC, Brownie AC \& Ling N 1980 Pro-adrenocorticotropin/ endorphin-derived peptides: coordinate action on adrenal steroidogenesis. Science 208 1044-1046.

Pham-Huu-Trung MT, de Smitter N, Bogio A, Bertagna X \& Girard F 1982 Responses of isolated guinea-pig adrenal cells to ACTH and pro-opiocortin-derived peptides. Endocrinology 110 1819-1821.

Rainey WE, Rodgers RJ \& Mason JI 1992 The role of bovine lipoproteins in the regulation of steroidogenesis and HMG-CoA reductase in bovine adrenocortical cells. Steroids 57 167-173.

Reader SCJ, Daly JR \& Robertson WR 1982 Effect of human plasma on the bioactivity of adrenocorticotrophin. Journal of Endocrinology $92449-455$.
Reaven E, Spicher M \& Azhar S 1989 Microvillar channels: a unique plasma membrane compartment for concentrating lipoproteins on the surface of rat adrenal cortical cells. Journal of Lipid Research 30 $1551-1560$.

Rees LH, Ratcliffe JG, Besser GM, Kramer R, Landon J \& Chayen J 1973 Comparison of the redox assay for ACTH with previous assays. Nature New Biology 241 84-85.

Schumaker VN \& Puppione DL 1986 Sequential flotation ultracentrifugation. Methods in Enzymology 128 155-170.

Simpson ER 1979 Cholesterol side-chain cleavage, cytochrome P450, and the control of steroidogenesis. Molecular and Cellular Endocrinology 13 213-227.

Simpson ER, Carr BR, Parker CR Jr, Milewich L, Porter JC \& MacDonald PC 1979 The role of serum lipoproteins in steroidogenesis by the human fetal adrenal cortex. Journal of Clinical Endocrinology and Metabolism 49 146-148.

Sinensky M, Minneman KP \& Molinoff PB 1979 Increased membrane acyl chain ordering activates adenylate cyclase. Journal of Biological Chemistry 254 9135-9141.

Sinha AK, Shattil SJ \& Colman RW 1977 Cyclic AMP metabolism in cholesterol-rich platelets. Journal of Biological Chemistry 252 3310-3314.

Slotte JP, Oram JF \& Bierman EL 1987 Binding of high density lipoproteins to cell receptors promotes translocation of cholesterol from intracellular membranes to the cell surface. Journal of Biological Chemistry 262 12904-12907.

Tait JF, Tait SAS \& Bell JBG 1980 Steroid hormone production by mammalian adrenocortical dispersed cells. Essays in Biochemistry 16 99-174.

Upton GV, Hollingsworth DR, Londe S, Lerner AB \& Amatruda TT Jr 1970 Comparison of purified and porcine ACTH in man. Journal of Clinical Endocrinology and Metabolism 30 190-195.

West DC, Sattar A \& Kumar S 1985 A simplified in situ solubilization procedure for the determination of DNA and cell number in tissue cultured mammalian cells. Analytical Biochemistry 147 289-295.

Whetton AD, Gordon LM \& Houslay MD 1983 Elevated membrane cholesterol concentrations inhibit glucagon-stimulated adenylate cyclase. Biochemical Journal 210 437-449.

Yaguchi H, Tsutsumi K, Shimono K, Omura M, Sasano H \& Nishikawa T 1998 Involvement of high density lipoprotein as substrate cholesterol for steroidogenesis by bovine adrenal fasciculo-reticularis cells. Life Sciences 62 1387-1395.

Received 17 December 1998

Revised manuscript received 10 February 1999

Accepted 2 March 1999 